\title{
Forest site classification in New Brunswick
}

\author{
by Colin Bowling ${ }^{1}$ and Vincent Zelazny ${ }^{2}$
}

\begin{abstract}
Six site classification field guides covering nine site regions were published in March, 1989. They completed the design phase of a province-wide site classification program begun in 1981. The site classification system is designed as an on-site, preharvest assessment tool for use in mature and overmature natural stands. It incorporates easily recognizable vegetation and soil characteristics to classify each stand into a Vegetation Type (VT), a Soil Type (ST), and a Treatment Unit (TU). Forest management and silvicultural interpretations are given for each TU, with the primary interpretation being site productivity.
\end{abstract}

\section{Résumé}

En mars 1989, six guides pratiques de classification des sites portant sur neuf régions ont été publiés. Ils complètent ainsi la phase du programme provincial de classification des sites, entrepris en 1981. Le système de classification est conçu comme un outil d'évaluation prérécolte destiné à être utilisé sur le terrain, dans les peuplements naturels âgés et surâgés. Il fait appel à des caractéristiques du sol et de la végétation faciles à identifier afin de classer chaque peuplement dans un type de végétation (VT), un type de sol (ST) et une unité de traitement (TU). Des considérations relatives à l'aménagement et à la sylviculture sont présentées pour chaque TU, notamment sur le potentiel du site.

\section{Introduction}

Forest site classification efforts in New Brunswick have progressed sporadically since 1937 when the province was part of Haliday's "Forest Classification for Canada." A very thorough review of subsequent attempts at site classification in Atlantic Canada is provided by Page et al. (1979). For New Brunswick in particular, three of these attempts were provincewide classification systems, namely Loucks (1962), the Canada Land Inventory program of the late 1960s (McCormack 1970) and the unpublished work of Crampton (1973).

Although the first two pieces of work have been useful for broad planning purposes, they are of very limited operational value to forest managers either because of their scale or because of a lack of sufficiently precise growth and yield data. Crampton could not find meaningful relationships between productivity and his classification units, which were based on Loucks' ecoregions, bedrock and surficial geology, soil drainage and relief. His work was not carried forward.

During the late 1970s, projections of a province-wide, 20 -year shortfall in softwood supply led to a series of policy decisions that drastically altered the way forest management was to be carried out in New Brunswick. In a very short time, the province's forest inventory system was redesigned and the forest resource photographed (true-colour) and interpreted at a scale of 1:12 500. All data were captured on a geographic information system (GIS) made up of a PRIME mini-computer and ARC/INFO software supplied by Environmental Systems Research Institute Corporation of California.

Wood supply analyses were to be done every five years, and along with operational silviculture decisions, were now the responsibility of the major forest companies. It became readily apparent that one of the biggest gaps in the information base on which much of the wood supply analyses depended, were reliable growth and yield data on a sitespecific basis, and the ability to represent spatially the distribution of sites across the landscape.

\footnotetext{
${ }^{1}$ Northwestern Ontario Forest Technology Development Unit, Ontario Ministry of Natural Resources, PO Box 5160, Kenora, Ontario, Canada P9N 3X9. ${ }^{2}$ New Brunswick Department of Natural Resources and Energy, Timber Management Branch, P.O. Box 6000, Fredericton, N.B. E3B 5H1. (To whom all enquiries should be addressed.)
}

In the spring of 1981, within the framework of this new forest management environment, an inter-agency group now called the New Brunswick Forest Site Classification Technical Committee proposed the design of a province-wide site classification system. The objective was to develop a system using the measurable features of the physical environment known to be principal determinants of stand productivity and silviculture treatment.

The provincial Department of Natural Resources and Energy was identified as the lead agency. A core of four to six people were hired on contract and funded through Federal-Provincial forestry subsidiary agreements. Much discussion ensued as to whether efforts should be map- or field guide-based, both approaches having their advantages and disadvantages. The field guide approach was chosen because of the short-term information needs, its lower cost, and because it was more site-specific and 'on the ground' than the mapping approach.

In addition to having productivity as its primary interpretation, the site classification system was designed as a preharvest, on-site assessment tool for use in mature and overmature stands. It was aimed at the field-trained forest technician, and used easily assessed soil and vegetation features that fit in well with operational activities.

\section{Approach}

The non-hierarchical site classification system of van Groenewoud and Ruitenberg (1982) provided an initial framework for field sampling. Four levels of classification, from general to specific, describe climate, geomorphology, regolith, and site (Table 1). Each level is defined quantitatively, through the use of environmental features known to affect tree growth and productivity. This is different from many existing forest site classification systems which define each level through indirect, synoptic measures.

For example, Loucks (1962) used major changes in climax forest cover on 'zonal,' or average, sites to delineate and map areas of similar macroclimate (ecoregions). Preliminary ecoregion boundaries were then finalized after consulting available weather data. In contrast, climatic regions as defined by van Groenewoud (1984), were derived from 
Table 1. The four-level site classification system of van Groenewoud and Ruitenberg (1982), used as the basis for the New Brunswick site classification system

\begin{tabular}{lll}
\hline Unit & Description & Remarks \\
\hline 1. Climatic region & $\begin{array}{l}\text { A region with a distinctive climate delineated by } \\
\text { multivariate statistical analysis of meteorological data }\end{array}$ & $\begin{array}{l}\text { These parameters constitute a broad control on forest } \\
\text { growth and form the framework for meso- and } \\
\text { microclimatic description. }\end{array}$
\end{tabular}

2. Geomorphologic The surface expression of a major bedrock formation or district

3. Regolith system group, modified by glaciation and fluvial erosion.

a) Form and texture of land-forms such as lodgement till, ablation till, outwash, alluvial deposits, etc.
These parameters provide the first-order controls on drainage, topography, mesoclimate and nutrient supply.

These parameters greatly affect drainage and limit nutrition availability within the regolith.

b) Lithologic-mineralogic composition (including percentage of material derived from different rock units and their secondary products) and structure (cleavage and fracturing) of the regolith material.
4. Site type
a) Soil profile characteristics
b) Microdrainage
c) Slope
d) Position on slope
e) Aspect
f) Microclimate, etc

multivariate analyses of 30 years of meteorological data collected across a province-wide network of weather stations.

Each approach has its strengths and shortcomings. Loucks' indirect approach was subject to forest cover differences responding not to climate alone, but also to changes in other ecological factors, such as fertility due to differences in geological materials, for example. Van Groenewoud's direct method was constrained by the availability of data (relative humidity data were not available, for example) and by the lack of weather stations in a large area of the province.

The concept of the edatopic grid was also used to help in stratification for sample plot selection. An edatopic grid is an arrangement of stand types (ordination) in two dimensions whose axes represent soil moisture regime (SMR) and soil nutrient regime (SNR) (Klinka and Carter 1990) (Figure 1). Stand types are arranged on the grid so that similar stands (with respect to SMR and SNR) are close together, dissimilar ones far apart. The assumption here is that SMR and SNR are major factors driving stand species composition and development within a climate region. Sampling was carried out in all portions of the edatopic grid in order to cover the complete range in both nutrient and moisture regime within a climate region.

Within this framework, tree growth, soils, and vegetation data were collected between 1982 and 1988 in approximately 2100 mature and overmature natural stands. All forest cover types were sampled, although proportionately more plots were established in softwood and softwood-hardwood forests than in hardwood forests because growth and yield data needs were much greater for softwoods.

As an understanding of the relationships among soil, vegetation, and productivity developed, the concepts of Site Region and Treatment Unit evolved. These are site units that draw together the essential information from the four levels of classification (as described in Table 1) to distinguish sites on the basis of productivity. They are intended to be practical and easy to identify from an operational standpoint.

A Site Region is a landscape unit recognized on the basis of regional climate as derived from meteorological data (van Groenewoud 1984) (Level 1 above), bedrock and physiography (van Groenewoud and Ruitenberg 1982) (Level 2 above), and the species composition of vegetation on zonal sites (Loucks 1962). Site Region boundaries result from the melding of all three information sources, in a attempt to maximize the strengths and minimize the weaknesses of each. There are nine Site Regions in the province (Figure 2).

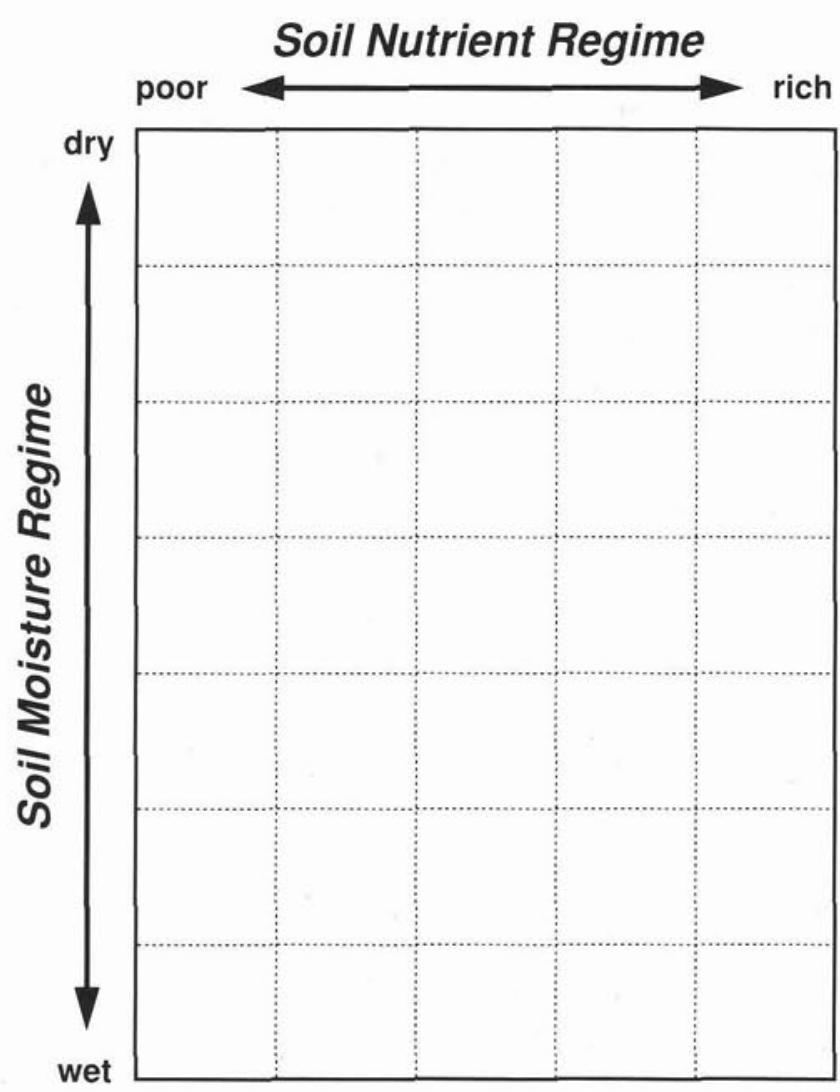

Figure 1. An edatopic grid showing relative nutrient and moisture regime cells. 


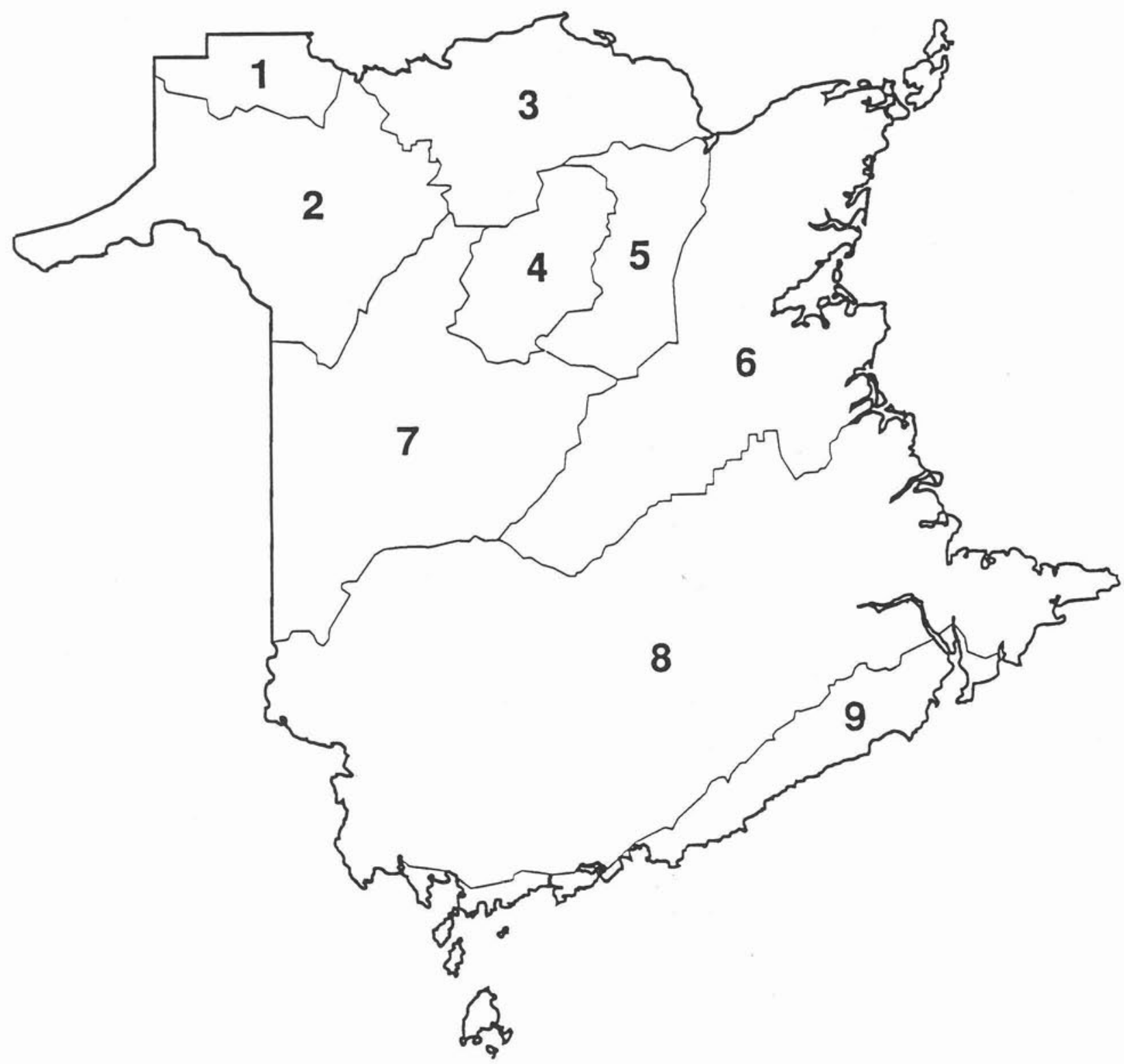

Figure 2. New Brunswick Site Regions. 1. Kedgwick, 2. Restigouche, 3. Upsalquitch, 4. Big Bald, 5. Sevogle, 6. Cains-Tracadie, 7. Napadogan-Tobique, 8. Harvey-Harcourt, 9. Fundy.

A Treatment Unit (TU) is a site-specific landscape unit with a relatively narrow range in both nutrient regime and drainage, and a certain level of productivity for commercial softwoods. Information collected at Levels 3 and 4 above are used to describe TUs, all within a hierarchical framework of Site Regions. A complete set of TUs, covering the observed range of ecological conditions, was developed separately for each Site Region. There are between eight and fifteen TUs within each Site Region.

\section{Field Sampling}

A circular plot $12 \mathrm{~m}$ in radius was established at a 'representative' portion of each stand sampled. Within the plot, trees, shrubs, herbs, grasses, sedges, ferns, clubmosses, lichens, liverworts, and mosses were identified and listed. Cover/abundance estimates were made for each plant using a scale from 1 ( $<8 \%$ of the plot covered) to $5(>64 \%)$, a modification of the octave scale of Gauch (1982).
A soil pit was dug within each plot and described as to horizonation, depth of rooting and mottling, coarse fragment content, texture, and other morphological characteristics. In addition, 20 pebbles were collected from the lowermost (usually $\mathrm{C}$ ) horizon for later lithological identification.

Where available, three or four dominant or co-dominant healthy, unsuppressed trees of the major coniferous species (white spruce (Picea glauca), red spruce (Picea rubens), black spruce (Picea mariana), balsam fir (Abies balsamea), and jack pine (Pinus banksiana)) were measured for total height, breast height age, and diameter at breast height. At the end of each plot establishment season (usually midSeptember), all plot data were collated to choose approximately $30 \%$ of the plots for revisits and detailed stem analysis during the following three months. By the end of 1988 , approximately 2600 trees on 580 plots had been felled, sectioned and measured. 


\section{Data Analysis \\ Vegetation}

One of the fundamental concepts behind the site classification system was that the vegetation and soil components of the landscape could be independently analyzed, sorted, and subsequently brought together and classified into meaningful units for operational forest management.

Vegetation data were analyzed for each Site Region separately, with the objective of developing a Site Regionspecific vegetation key. Taking a cue from site classification efforts in Ontario (Jones et al. 1982), this was accomplished by first using ordination and classification programs (DECORANA and TWINSPAN; Gauch 1982) to give an initial classification. A key-simulation program was then developed to refine the classification. Resulting Vegetation Types (VTs) represent the entire range of mature vegetation communities occurring naturally across the landscape within the limits of each Site Region's dataset (Figure 3).

A VT is a recurring, mature vegetation community determined by the presence or abundance of certain indicator plants. Each VT is described in terms of its common or distinctive overstory and understory vegetation components (Table 2). The species composition of any vegetation community reflects, among other things, soil conditions and processes related to plant nutrition and site productivity. This property of vegetation communities arises from the tendency of individual species to survive under certain soil conditions, and to fail under others. Species composition information conveyed by VTs also has important implications for natural stand development and competition.
Soils

As with vegetation, soils data were analyzed with the objective of deriving a Site Region-specific soil type (ST) key. In contrast to the VT key, divisions of a ST key were not designed to distinguish naturally occurring units per se, but to maximize the distinctiveness of STs in terms of tree productivity. As a result, STs are empirical, not taxonomic units. Specifically, each ST is a grouping of morphologically similar soils having a certain productivity as determined by site index (height $(\mathrm{m})$ at 50 years breast height age) of dominant trees in natural stands. Soil types are identified through the use of variables such as drainage, depth to a compact layer, rooting space, mode of deposition, lithology, coarse fragment content, and horizon thickness.

Before detailed analysis began, decisions were made a priori to analyze organic soils (forest floor depth $>40 \mathrm{~cm}$ ) separately from mineral soils, to exclude old fields (Ap horizon present), and to analyze well and rapidly drained sites as a group, and moderately-well drained and wetter mineral soils as another group. Given these decisions, variables selected at lower levels of a ST key were present because they usually resulted in significant differences in site index for at least one of the major coniferous species listed earlier (Figure 4).

\section{Productivity}

Site quality effects on yield are most strongly expressed in the growth of managed stands, where the impact on yield of variation in stocking, defoliation by insects, disease, and

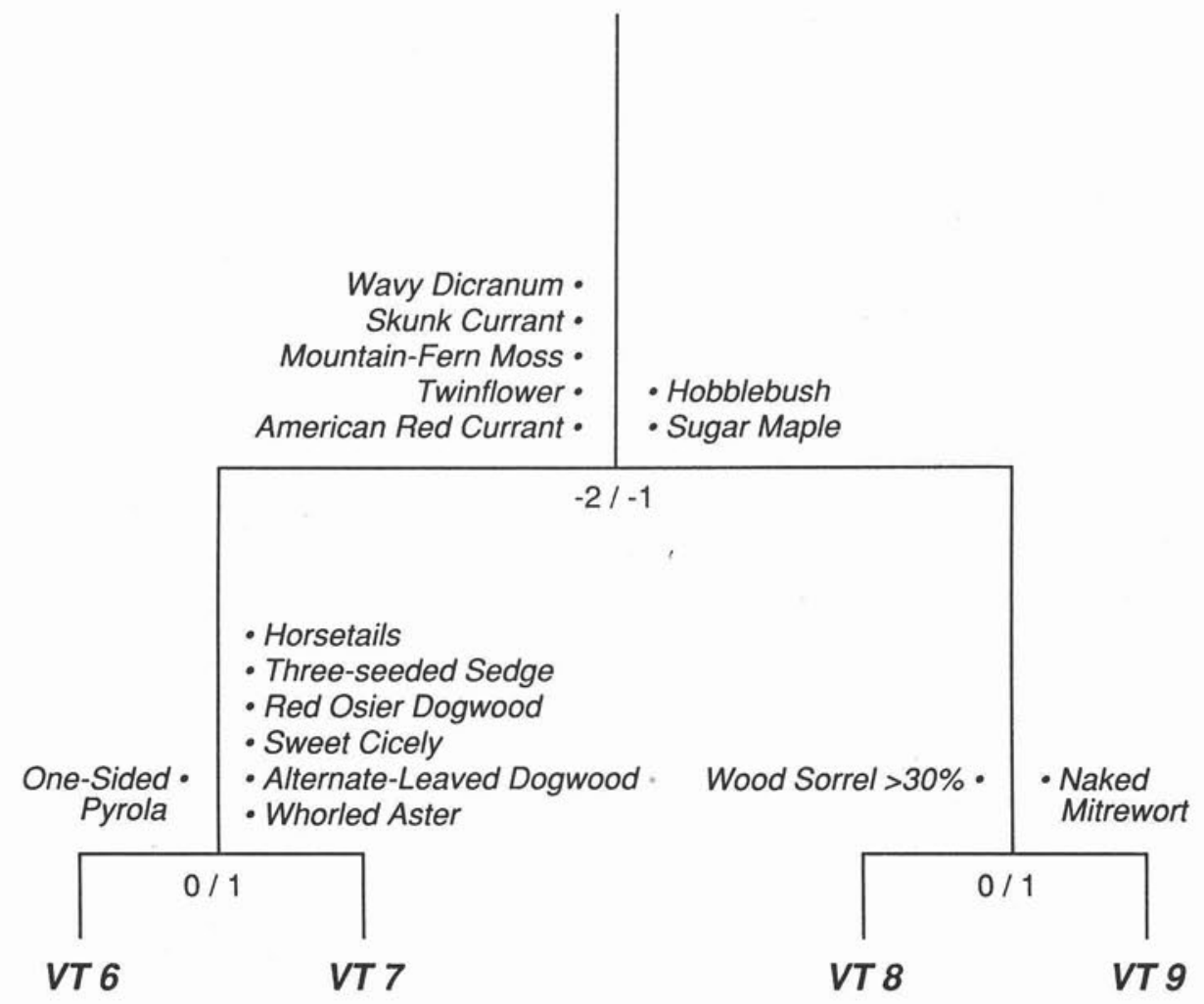

Figure 3. A portion of the Vegetation Type (VT) field key for the Restigouche site region. The dichotomous key employs common names for species because this presentation format was preferred by the client group. Full species nomenclature and directions for keying-out sites in the field are provided in the New Brunswick site classification field guides (from Zelazny et al. 1989). 
Table 2. Soil Types (STs) and Vegetation Types (VTs) in the Restigouche site region. STs are defined in terms of local site or soil profile characteristics and VTs are characterized by dominant overstory species and dominant and/or distinctive understory species (after Zelazny et al. 1989).

\begin{tabular}{lll}
\hline Soil type & Soil type name & Characteristic soil features \\
\hline ST 1 & Wet & Average duff thickness $=16 \mathrm{~cm}$ \\
ST 2 & Moist & Moderately well and imperfectly drained \\
ST 3 & Calcareous & Derived from calcareous rocks or sediments \\
ST 4 & Compact basal till & Mean maximum rooting depth $=38 \mathrm{~cm}$ \\
ST 5 & Deep loamy & Mean maximum rooting depth $=50 \mathrm{~cm}$ \\
ST 6 & Poor loamy & Derived from acidic igneous rocks \\
ST 7 & Droughty & Rapidly drained, usually with a coarse-textured C horizon \\
\hline Vegetation type & Dominant overstory species ${ }^{1}$ & Dominant and/or distinctive understory species \\
\hline VT 1 & bS rS bF & Pleurozium schreberi, Bazzania trilobata \\
VT 2 & bF rS & Cornus canadensis, Oxalis montana \\
VT 3 & rS bF wB & Bazzania trilobata, Lonicera canadensis \\
VT 4 & bF wB rM & Clintonia borealis, Dicranum scoparium \\
VT 5 & bF yB wS & Oxalis montana \\
VT 6 & bF wS & Hylocomium splendens, Viola spp. \\
VT 7 & bF cE wS & Rubus pubescens, Mitella nuda \\
VT 8 & bF yB wS & Clintonia borealis, Galium triflorum \\
VT 9 & bF wS yB & Corylus cornuta, Viola spp. \\
VT 10 & yB sM bF & Dryopteris spp., Lycopodium lucidulum \\
VT 11 & Be sM & Acer pensylvanicum \\
VT 12 & sM yB Be & Acer spicatum, Streptopus roseus \\
\hline
\end{tabular}

${ }^{\mathrm{I}} \mathrm{bS}=$ black spruce, $\mathrm{rS}=$ red spruce, $\mathrm{wS}=$ white spruce, $\mathrm{bF}=$ balsam fir, $\mathrm{Ce}=$ eastern white cedar, $\mathrm{wB}=$ white birch, $\mathrm{yB}=\mathrm{yellow}$ birch, $\mathrm{rM}=$ red maple, $\mathrm{sM}=$ sugar maple, $\mathrm{Be}=$ beech.

competition by undesireable species has been eliminated or at least minimized. Unfortunately, very few older plantations existed by site type or species to provide a sufficiently large data base for destructive sampling. As a result, stem analysis of dominant trees from natural stands was seen as the only reliable means to obtain growth and yield information by site.

Many site quality studies have successfully used site indices obtained from measurements of total tree height and breast height or total age as a measure of site quality, particularly for fire-origin or intolerant species (Carmean 1975).
However, both balsam fir and red spruce are shade-tolerant and may display height growth patterns caused by variable overstory competition levels rather than by a site's inherent capability for tree growth, and these patterns can be uncovered only with stem analysis.

In addition, stem analysis revealed sometimes dramatic height and diameter growth reductions coincident with moderate to high levels of budworm feeding. These reductions could be easily seen on balsam fir and white spruce discs, and required adjustments to the growth

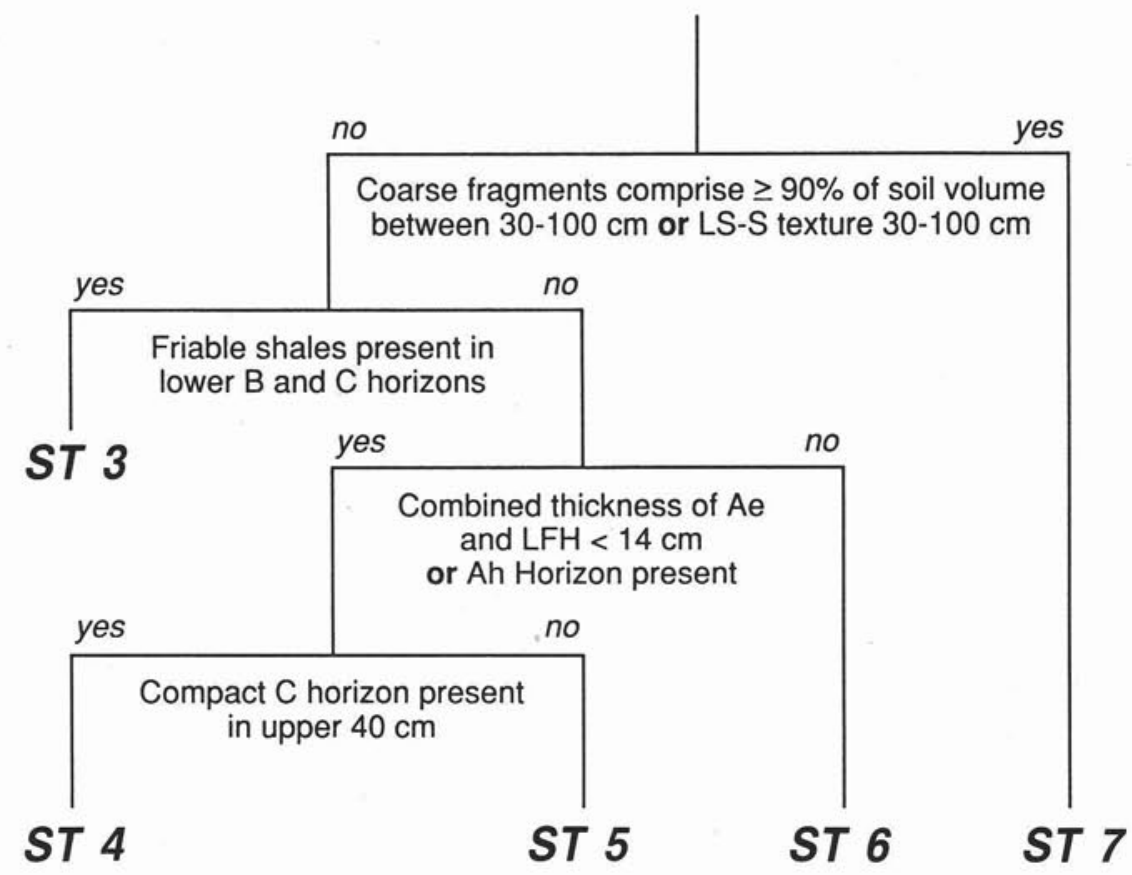

Figure 4. A portion of the Soil Type (ST) field key for the Restigouche site region. The dichotomous key employs a number of parameters that are determined from local site or soil profiles in the field. Aids for describing soils and directions for use of the key are provided in the New Brunswick site classification field guides (from Zelazny et al. 1989). 
profiles. Procedures developed by Carmean (1972) were followed to adjust for the underestimation in each year's actual total height growth as a result of cutting discs below and not through a terminal whorl.

To estimate site-specific managed stand yields on a volume basis from tree data collected in natural stands, the best $\mathrm{TU} /$ species growth rates from these stem analysis data were submitted to an unpublished plantation growth model developed in-house by T. Erdle.

\section{Treatment Unit Derivation}

All possible combinations of STs and VTs and their TU designations are illustrated in a Site Region-specific TU grid. TU membership of each cell on the grid was assigned with two goals in mind: first, to maximize productivity differences between TUs, and second, to minimize soil and vegetation differences within TUs (Figure 5).

Each TU is identified by the number of the space that includes the square where the ST row and VT column intersect. Not all cells were represented by sample plots. Blank cells thought to be an ecologically valid combination but simply not sampled were interpolated into an adjacent TU. A dotted cell indicates not only no data for that particular ST-VT combination, but that the combination was deemed to not occur naturally.

\section{Testing of the Keys}

Approximately $15 \%$ of the total number of plots established within each Site Region were selected randomly from the dataset and not used in key development. Instead, these were used for in-house testing of the resulting keys and TU designations. In addition, other projects within both the provincial and federal forestry services had used the site classification datasheets and methodologies to collect plotspecific information. These data were graciously made available to be part of a test data set as well.

Testing was meant to check the precision of the keys and to uncover potential errors. At the VT and ST level, 'correct' classification meant that a plot had to be classified into a VT or ST that was a reasonable expression of that particular plant community or soil type. If, for example, a test plot was a wet black spruce-Sphagnum moss community and the VT or ST keys classified it into a moderately to well drained balsam fir-white spruce site, it would be recorded as a total misclassification.

At the TU level, if the misclassification of either the VT or the ST did not result in a change in TU, and if the site indices were within one standard deviation of the TU mean for most species, the classification was deemed successful. Averaged across all Site Regions, the VT and ST keys gave correct classifications approximately $75 \%$ of the time. When based on TUs, however, results improved to as high as $95 \%$ in some Site Regions. Complete misclassification occurred less than $10 \%$ of the time, a figure judged to be acceptable for this stage of evolution of the site classification system.

This type of testing is only one part of creating a usable site classification system. The other major criterion is whether it can be used effectively in the field. This was tested by having other projects use preliminary versions of the keys and data forms, and by operational trials in co-operation with forestry companies.

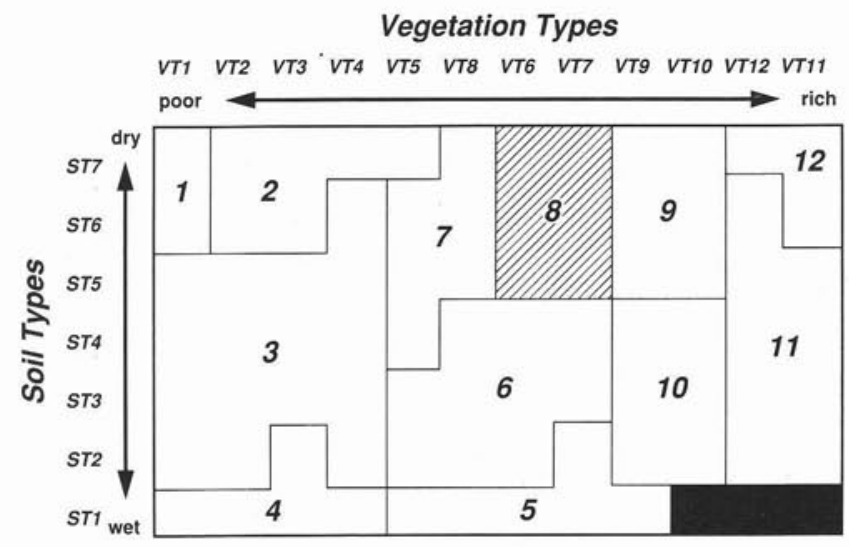

Figure 5. Treatment Unit (TU) grid for the Restigouche site region. Poor and Rich are relative nutrient rankings, and Dry and Wet are relative moisture regime rankings. Each of 12 TUs occupies a different portion of the nutrient/moisture regime grid. For example, TU 8 is highlighted in the diagram and includes sites that are keyed-out to Vegetation Type (VT) 6 or 7, and Soil Types (ST) 5, 6 or 7 (VT and ST names as in Table 2) (From Zelazny et al. 1989).

\section{Current Situation}

\section{Field Guides}

Six field guides covering nine Site Regions were published in March, 1989. This completed the original objective of designing a site classification system. In addition to the classification tools (the VT key, ST key, and TU grid) each field guide contains:

- Introductory information: includes step-by-step instructions for using the guide and a general ecological description of each Site Region.

- Verification information: includes material summarizing the average characteristics of VTs and STs to aid in verifying the results obtained with the keys.

- Interpretations: these appear on the TU interpretation sheets and contain information about managed stand yield, site index in natural stands, natural regeneration densities, and erosion, compaction, and windthrow hazards. Site index curves were developed from the stem analysis data (Ker and Bowling 1991) and are included in the field guides. Summaries of the derivation and definitions of these interpretations are also given.

- Soil description aids: include texture assessment key, horizon descriptors and drainage key.

A glossary of terms, a list of plants organized by life form and sorted by Latin name, a list of references, and a Site Region map in a back pouch completes each field guide.

\section{Implementation}

Since the publication of the field guides in 1989, all forest companies with responsibilities on Crown land have participated in implementing site classification. In New Brunswick today, the site classification system is being used to forecast yield from managed stands in wood supply analysis, and to priorize regenerating areas for silvicultural treatment on the basis of predicted managed stand yield. 
Initially, the goal of the implementation program was to increase gradually the amount of on-the-ground preharvest site classification to $100 \%$ of harvest blocks by 1991 . After the initial year, a number of companies expressed concern about the cost of obtaining these fairly large volumes of data in relation to the value of the information gained. After much discussion, the approach shifted to put greater emphasis on TU prediction based on existing sources of mapped resource information, rather than intensive field checks in all blocks.

Specifically, it was proposed that all existing site resource information be compiled into a uniform map coverage to be used for predicting TUs. With appropriate site quality maps, candidate blocks for precommercial thinning or planting could be prioritized on the basis of predicted site quality, and field-checked to verify the prediction. As a result, the number of areas to be ground-checked decreased by twothirds from the original $100 \%$ proposal. Accurate site quality information confirmed by ground-truth could then be used to guide the process for final selection of silvicultural treatment areas.

Through the winter of 1989-90, existing land and forest resource information was compiled to produce ST and VT maps and by extension, TU maps. Soil types were mapped by interpreting and compiling existing sources of geology and soils information, as well as the approximately 3600 observations of soil and vegetation collected between 1982 and 1990. Compiled map sources included soil surveys, regolith system maps, surficial geology maps, bedrock geology maps, topographic maps, and granular aggregate resource maps. Soil association polygons were inferred from compiled data. Some soil associations were modified from the central concept of recognized soil associations of New Brunswick (Fahmy et al 1986) in order to be directly interpretable as STs. For example, some shallow-to-bedrock soil associations were redefined as those showing bedrock within the upper $50 \mathrm{~cm}$, rather than $1 \mathrm{~m}$. STs were delineated on 1:50 000 base maps and digitized.

What remains to be done is essentially a GIS dataprocessing exercise. Vegetation types are estimated using algorithms developed from observed correlations between the provincial forest inventory map units (which denote species composition, development stage, and crown closure) and VT. When the midpoint of our VT-interpreted forest inventory polygons are intersected with the ST layer, we will have the means to calculate TU.

In spite of the possible information weaknesses in this process, we believe our maps to be acceptably accurate for many planning purposes related to wood supply analysis or silviculture. This process is now complete for all Crown lands. Maps will be updated with new information on a 5-year cycle to coincide with companies' revisions to their 25-year management plans as stipulated under the Crown Lands and Forests Act. Within the next planning cycle we anticipate (1) a revision of the forest inventory and (2) the acquisition of digital terrain maps, both of which should improve TU predictions from mapped resource information.

\section{Verification}

Testing of the site classification system is being conducted at both the stand and landscape levels. Observations of growth in managed stands were taken in 1989 and 1990 and are being compared with the stem analysis data from natural stands. Managed stand yield estimates will be revised using data from an inter-agency permanent sampling program (Upshall 1990).

At the landscape level, completion of the TU map database will permit analyses of the potential impact of site quality on yield from individual forests, given that we have now linked estimates of (1) the area of land in each site class and (2) a stratification of stands by development stage and species composition.

\section{Other Work}

Occurence of natural regeneration appears to be related to the species composition of pre-harvest stands and the condition of the overstory (Ruel 1989). In New Brunswick, natural regeneration of balsam fir and spruces is often prolific. Advance regeneration density estimates of spruce, balsam fir, and cedar (Thuja occidentalis) summarized by VT and included in the TU interpretation sheets were obtained from a cutover response project (Godin 1985, Zelazny 1987, Zelazny and Hayter (1991)). If the present site classification system is further developed to predict preharvest advance regeneration abundance, then we will be a step closer to integration of harvesting system, stand and site to achieve regeneration objectives.

A study has been undertaken by our staff to determine the effectiveness of the current site classification keys in young stands and cutovers. Preliminary results suggest that indicator species very rarely go to local extinction from areas disturbed by harvesting, although the relative post-harvest abundance of a species may be substantially changed when compared to its pre-harvest level.

Other agencies are also doing work that could eventually improve interpretations in the field guides. Forestry CanadaMaritimes is conducting growth and yield studies. A study of the effects of nutrient loss in biomass removal is underway by the same agency in co-operation with J.D. Irving Ltd. A study investigating the effects of different combinations of site preparation and TU on early survival and growth of planted black and white spruce is underway at the University of New Brunswick in co-operation with Fraser Inc. The Mineral Resources Branch of the provincial Department of Natural Resources and Energy has been mapping regolith systems in co-operation with the site classification effort for the past seven years. These data are valuable in improving the soils resource information.

Some TUs have little or no data for softwood productivity, and for some softwood species such as tamarack (Larix laricina) or Norway spruce (Picea abies) little productivity data exist and more sampling is needed. In addition, some forest companies rely heavily on the hardwood resource, yet growth and yield estimates by site for almost all hardwood species are only now starting to be collected for New Brunswick sites.

\section{Acknowledgements}

The authors are indebted to Drs. Louis Bélanger and Russell Wells for valuable comments on the original manuscript. Site classification efforts in New Brunswick have been a team effort, and we would like to thank all those involved over the years. Special mention to Drs. David MacLean and Herman van Groenewoud of Forestry Canada-Maritimes, and to representatives of New Brunswick marketing boards for making their data available for key testing. 


\section{References}

Carmean, W.H. 1972. Site index curves for upland oaks in the Central States. For. Sci. 18: 109-120.

Carmean, W.H. 1975. Forest site quality evaluation in the United States. Advan. Agron. 27: 209-269.

Crampton, C.B. 1973. Forest land productivity classification for the Maritime Provinces. Unpub. rep.

Fahmy, S.H., H.W. Rees, and J.K. MacMillan. 1986. Soils of New Brunswick: a first approximation. N.B. Dept. Agric. 105 p.

Gauch Jr., H.G. 1982. Multivariate analysis in community ecology. Cambridge Univ. Press. 298 p.

Godin, B. 1985. Forecasting cutover response in New Brunswick. A guide for silvicultural decision making. Dept. For. Mines Energy, Prov. N.B. 71 p.

Haliday, W.E.D. 1937. A forest classification for Canada. Can. Dept. Mines Resour., For. Serv. Bull. 89.

Jones, R.K., G. Pierpoint, G.M. Wickware, J.K. Jeglum, R.W. Arnup and J.M. Bowles. 1983. Field guide to forest ecosystem classification for the Clay Belt, Site Region 3E. Ont. Min. Nat. Resour. Queen's Printer, Toronto, Ont. 161 p.

Ker, M.F. and C. Bowling. 1991. Polymorphic site index equations for four New Brunswick softwood species. Can. J. For. Res. 21: 728-732.

Klinka, K. and R.E. Carter. 1990. Relationships between site index and synoptic environmental factors in immature coastal Douglas-fir stands. For. Sci. 36: 815-830.

Loucks, O.L. 1962. A forest classification for the Maritime provinces. For. Res. Br., Can. Dept. For. 167 p.

McCormack, R.J. 1970. The Canada Land Inventory land capability classification for forestry. Rept.\#4-1967 2nd ed. 1970. Dept. Reg. Econ. Expan.

Page, G., H. van Grounewoud and J.C. Lees. 1979. Forest site evaluation in the Atlantic region. Paper presented at the Can. Soc. Soil Sci., Fredericton, N.B. 16 p.

Ruel, J-C. 1989. Importance de la régénération préexistante dans les forêts publiques du Québec. Ann. Sci. For. 46: 345-359.

Upshall, J.R.B. 1990. 1989 permanent sampling program annual report. Timber Mgt. Br., N.B. Dept. Nat. Resour. Energy. 28 p.

van Groenewoud, H. 1984. The climatic regions of $\mathrm{New}$ Brunswick: a multivariate analysis of meteorological data. Can. J. For. Res. 14: 389-394.

van Groenewoud, H. and A.A. Ruitenberg. 1982. A productivity oriented forest site classification system for New Brunswick. Can. Dept. Environ., Can. For. Serv., Maritimes For. Res. Cent., Infor. Rep. M-X-136. 9 p.

Zelazny, V. 1987. Forecasting cutover response in New Brunswick: unpub. project summary 1986-87, Timber Mgt. Br., N.B. Dept. Nat. Resour. Energy. 39 p.

Zelazny, V. and M. Hayter. 1991. Predicting natural regeneration abundance with a productivity-oriented site classification. In Simpson, C.M. (ed.) Proceedings of a conference on natural regeneration management, Fredericton, N.B., 27-28 March 1990. ISBN-0-662-18893-4.

Zelazny, V.F., T.T.M. Ng, M.G. Hayter, C.L. Bowling, and D.A. Bewick. 1989. Field guide to forest site classification in New Brunswick. Can.-N.B. For. Subsid. Agree. Publ., N.B. Dept. Nat. Resour. Energy, Fredericton, N.B. (6 handbooks, unpaginated).

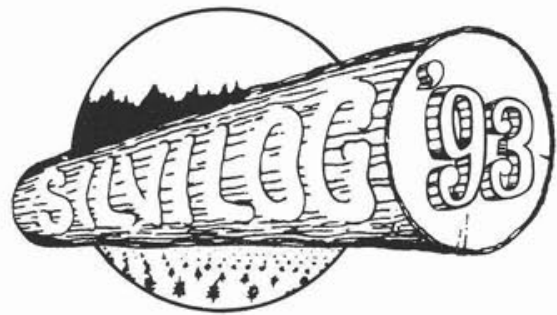 \\ Planning your annual meeting?}

\section{Plan it around Silvilog'93}

Sponsored by Forestry Canada and hosted by the Ontario Ministry of Natural Resources, Silvilog '93 - Caring For Our Woodlands, will be held Sept. 15-18, 1993 at the Copeland Crown Forest, about a 15-minute drive north of Barrie, Ont.

Through working exhibits, displays and seminars, Silvilog '93 will show small woodlot owners or managers and educators how to make the best, widest and most environmentally responsible use of woodlands, from harvesting to improving wildlife habitat.

See the latest equipment, learn the latest techniques, all in a woodlands setting.

For more information, contact: Bill Hardy, Project Manager, Silvilog '93, Ontario Ministry of Natural Resources, Box 605, 10 Oxford Ave., Brockville, Ont. K6V 5Y8. Phone (613) 342-8524. FAX: (613) 342-7544. 